\title{
安徽沿淮地区优质高产常规粳稻品种篮选及特征特性
}

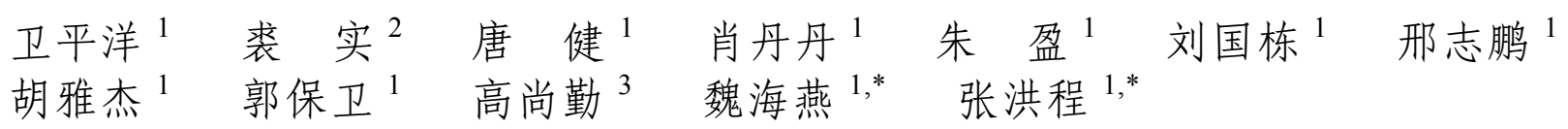

\begin{abstract}
${ }^{1}$ 扬州大学江苏省作物遗传生理重点实验室 / 扬州大学农业部长江流域稻作技术创新中心 / 粮食作物现代产业技术协同创新中心, 江苏扬州 $225009 ;{ }^{2}$ 江苏省农业科学院种质资源与生物技术研究所, 江苏南京 $210014 ;{ }^{3}$ 安徽省凤台县农业技术推广中心, 安徽淮南 232100
\end{abstract}

摘 要: 以 74 个常规粳稻品种(品系)为材料, 根据产量和食味值分为高产优质、高产不优质、中产优质和中产不优 质 4 种类型。选用高产优质、高产不优质和中产优质 3 种类型共 9 个品种, 研究其产量、品质差异及其高产优质形 成的特征特性, 以期为安徽沿淮地区适宜品种的篮选、种植推广提供科学依据和理论支撑。结果表明, 中产类型与高 产类型粳稻在产量上有极显著差异, 2017 年和 2018 年, 中产优质类型产量比高产优质类型、高产不优质类型分别低 $16.95 \% 、 16.76 \%$ 和 $16.52 \% 、 16.33 \%$ 。2 017 年, 与高产不优质类型相比, 高产优质类型和中产优质类型的直链淀粉含 量分别低 $39.31 \% 、 42.63 \%$; 胶稠度分别长 $22.06 \% 、 19.12 \%$; 蛋白质含量分别低 $11.60 \% 、 17.78 \%$ 。这些高产优质粳 稻品种特征特性主要表现为, 产量在 $8.35 \sim 9.16 \mathrm{t} \mathrm{hm}^{-2}$, 单位面积穗数在 $310 \times 10^{4} \sim 320 \times 10^{4} \mathrm{hm}^{-2}$ 之间, 每穗粒数在 140 左右, 千粒重在 $25 \mathrm{~g}$ 以上; 食味值评分在 $60 \sim 74$, 胶稠度长度在 $80 \sim 90 \mathrm{~mm}$, 蛋白质含量在 $6 \% \sim 8 \%$ 。

关键词：沿淮地区; 粳稻; 产量; 品质; 品种篮选

\section{Screening and characterization of high-quality and high-yield japonica rice va- rieties in Yanhuai region of Anhui province}

WEI Ping-Yang ${ }^{1}$, QIU Shi ${ }^{2}$, TANG Jian ${ }^{1}$, XIAO Dan-Dan ${ }^{1}$, ZHU Ying ${ }^{1}$, LIU Guo-Dong ${ }^{1}$, XING Zhi-Peng ${ }^{1}$, HU Ya-Jie ${ }^{1}$, GUO Bao-Wei ${ }^{1}$, GAO Shang-Qin ${ }^{3}$, WEI Hai-Yan ${ }^{1, *}$, and ZHANG Hong-Cheng ${ }^{1, *}$

\footnotetext{
${ }^{1}$ Jiangsu Key Laboratory of Crop Genetics and Physiology / Innovation Center of Rice Cultivation Technology in Yangtze Valley, Ministry of Agriculture / Co-Innovation Center for Modern Production Technology of Grain Crops, Yangzhou University, Yangzhou 225009, Jiangsu, China; ${ }^{2}$ Institute of Germplasm Resources and Biotechnology, Jiangsu Academy of Agricultural Sciences, Nanjing 210014, Jiangsu, China; ${ }^{3}$ Extension Center of Agriculture Technology in Fengtai County of Anhui Province, Huainan 232100, Anhui, China
}

\begin{abstract}
A field experiment was conducted with 74 conventional japonica rice varieties (lines), which were divided into four types according to the yield and taste value, i.e. high yield with good quality (HG), high yield with bad quality (HB), medium yield with good quality (MG), and medium yield with bad quality (MB). Among them, HG, HB, MG were weed to analyze their yield, quality differences and characteristics in HG formation, providing a scientific basis and theoretical support for screening, planting and extending the suitable varieties in Yanhuai area of Anhui province. The yield of MG was $16.95 \%$, 16.76\%, and $16.52 \%, 16.33 \%$ lower than that of HG type and HB type, respectively in 2017 and 2018. In 2017, compared with HB type, HG and MG types decreased by $39.31 \%$ and $42.63 \%$ in amylose content, increased by $22.06 \%$ and $19.12 \%$ in length of gel consistency, and decreased by $11.60 \%$ and $17.78 \%$ in protein content. The characteristics of these HG japonica rice varieties were mainly as follows: the yield was $8.35-9.16 \mathrm{t} \mathrm{hm}^{-2}$, the number of panicles per unit area was $310 \times 10^{4}-320 \times 10^{4} \mathrm{hm}^{-2}$, the grain number per panicle was around 140, the 1000-grain weight was over $25 \mathrm{~g}$; the taste value was $60-74$, the length of gel consistency was $80-90$
\end{abstract}

本研究由国家重点研发计划项目(2016YFD0300503)，江苏省重点研发计划项目(BE2016344)，江苏省农业科技自主创新基金 (CX[15]1002), 扬州大学拔尖人才计划和江苏省农业三新工程(SXGC[2017]294)资助。

This study was supported by the National Key Research Program (2016YFD0300503), the Key Research Program of Jiangsu Province (BE2016344), the Major Independent Innovation Project in Jiangsu Province (CX(15)1002), the Program for Scientific Elitists of Yangzhou University, and the Three New Agricultural Engineering Fund of Jiangsu Province (SXGC[2017]294).

* 通信作者(Corresponding authors): 张洪程, E-mail: hczhang@yzu.edu.cn; 魏海燕, E-mail: wei_haiyan@163.com 第一作者联系方式: E-mail: 2918052418@qq.com

Received (收稿日期): 2019-08-14; Accepted (接受日期): 2019-12-26; Published online (网络出版日期): 2020-01-15.

URL: http://kns.cnki.net/kcms/detail/11.1809.s.20200115.1046.010.html 
$\mathrm{mm}$, and the protein content was between $6 \%$ and $8 \%$.

Keywords: Yanhuai region; japonica rice; yield; quality; variety screening

我国约 $60 \%$ 的人口以稻米为主食, 其中粳米是 国人喜食的主要口粮 ${ }^{[1]}$ 。特别是近年来, 北方的“面 食改米食”和南方的“籼米改粳米”趋势明显 ${ }^{[1-4]}$, 更 加大了稻米市场对粳米的需求量。我国常年的水 稻种植面积为 2860 3000 万公顷, 其中 $25.5 \%$ 是粳 稻 $^{[5]}$ 。中国水稻研究所相关调查结果显示 ${ }^{[6]}$, 粳米消 费量每增加 $0.14 \%$ ，农村居民人均收入提高 $1 \%$ 。从 长远来看, 坚持和扩大粳稻的生产, 提高粳稻总产 量和品质, 对保障粮食安全、促进社会稳定具有重 要的现实意义。

我国的粳稻生产以“秦岭-淮河”一线为界, 可分 为南方和北方两大稻区。全国 906.7 万公顷粳稻播 种面积和 6500 万吨的稻谷总产量中, 南方稻区分别 占比 $46.8 \%$ 和 $48.5 \%{ }^{[7]}$ 。南方稻区中, 安徽省是重要 的粳稻生产省份之一。近年来, 全省年粳稻种植面 积接近 70 万公顷, 占全省水稻种植面积的 $30 \%$ 左 右。但安徽长期以籼稻种植为主, 缺乏适应性强、 高产优质的粳稻品种。目前安徽省自主选育并应用 的粳稻品种主要有皖稻 68 、安选晚 1 号、皖圼系和 当育粳系 ${ }^{[8]}$, 其种植面积合计占全省粳稻的 $22.4 \%$, 其余均是从江苏、浙江等省份引进的品种, 包括嘉 花 1 号、镇稻系列、武运粳系列等, 其种植面积合 计占全省粳稻的 $77.6 \%$ 。因此, 培育和筛选适合安徽 地区种植的抗逆性强、优质稳产粳稻品种就成为进 一步扩大安徽粳稻生产亟待解决的问题。

对于适宜地区高产优质水稻品种的篮选, 一 直是水稻研究的重点、难点。产量上, 前人通过篮 选认为, 较高的每穗粒数和结实率是高产的主要 原因 ${ }^{[9]}$; 品质上, 主要从稻米的加工、外观、蒸煮食 味、营养品质等方面进行節选, 指标是䊁米率、整 精米率、严白度、严白率、直链淀粉含量、胶稠度、 蛋白质含量等, 并按国标将它们分为 $1 、 2 、 3$ 级。于 洪兰等 ${ }^{[10]}$ 研究东北地区不同穗型水稻产量与食味值之 间关系认为, 单位面积穗数 320 万穗 330 万穗 $\mathrm{hm}^{-2}$, 每穗颖花数 150 170 个的品种更具高产优质的潜力; 而钟旭华等 ${ }^{[11-12]}$ 则认为穗数过多会影响群体受光条 件, 不利于高产的形成, 大穗型水稻存在籽粒异步 灌浆现象, 弱势粒灌浆结实差严重限制了高产潜力 的发挥与优良品质的形成 ${ }^{[13]}$ 。

前人主要以产量和国标中主要品质指标篮选水 稻品种, 尽管有一些品种在高产的同时能达到国标
三级或二级米的标准, 但是在市场上, 其适口性还 难以获得消费者的认可。本文以生产上现有主推品 种和近年来育种单位培育的共计 74 个粳稻品种(系) 为材料, 根据其产量与食味值的差异, 通过聚类分 析, 篮选出生产上广泛应用的高产优质、中产优质 和高产不优质 3 种类型, 又从每种类型篮选出最具 代表性的 3 个品种(系), 系统比较 3 种类型常规粳稻 各品质指标与产量及其构成因素间的差异及相互关 系, 阐明其品种特征, 旨在为安徽粳稻新品种的选 育及高产、优质的稻作生产实践提供参考依据和理 论支撑。

\section{1 材料与方法}

\section{1 供试材料}

选用镇稻 99、徐稻 9 号、南粳 2728、南粳 9108、 南粳 505、连粳 12、宁粳 4 号、宁粳 7 号、淮稻 5 号、华粳 8 号、苏秀 867、连粳 15、武运 5051、扬 粳 1612、苏香粳 3 号、松早香 1 号等共 74 个常规 粳稻品种, 研究其在安徽沿淮地区的产量品质特 征。将 74 个品种分为高产优质、高产不优质、中产 优质和中产不优质 4 种类型, 根据生产需要和市场 需求筛选出高产优质、高产不优质和中产优质 3 种 类型, 每种类型选出有代表性的 3 个品种, 分别是 高产优质品种徐稻 9 号、南粳 9108、南粳 505; 高 产不优质品种武运 5051、扬粳 1612、华粳 8 号; 中 产优质品种福粳 1606、苏香粳 3 号、松早香 1 号。

\section{2 试验设计}

试验于 2017-2018 年, 在安徽省淮南市凤台县 现代农业示范园区进行。试验田前茬为小麦, 土壤 质地为黏土, 地力中等, 含有机质 $27.1 \mathrm{~g} \mathrm{~kg}^{-1}$ 、全氮 $1.7 \mathrm{~g} \mathrm{~kg}^{-1}$ 、碱解氮 $86.6 \mathrm{mg} \mathrm{kg}^{-1}$ 、速效磷 $34.3 \mathrm{mg} \mathrm{kg}^{-1}$ 、 速效钾 $77.7 \mathrm{mg} \mathrm{kg}^{-1}$ 。5 月 19 日播种, 6 月 15 日移栽。 育积方式为廷苗育积, 栽插密度为 27.8 万穴 $\mathrm{hm}^{-2}$ (行株距为 $30 \mathrm{~cm} \times 12 \mathrm{~cm}$ ), 每穴 4 本栽插。每处理 3 次 重复; 小区面积为 $15 \mathrm{~m}^{2}$ 。氮肥施用量为 $270 \mathrm{~kg} \mathrm{hm}^{-2}$ 。 毯苗机插秧苗基肥：分藍肥：穗肥=3.5：3.5：3.0。 分菜肥于移栽后 $7 \mathrm{~d}$ 施用, 穗肥于倒四叶期施用。氮 $($ 纯 $\mathrm{N})$ ：磷 $\left(\mathrm{P}_{2} \mathrm{O}_{5}\right)$ ：钾 $\left(\mathrm{K}_{2} \mathrm{O}\right)$ 比例为 $2 ： 1 ： 2$, 磷肥一 次性基施, 钾肥分别于耕翻前、拔节期等量施入。 水分管理及病虫草害防治等相关的栽培措施均按照 高产栽培要求实施。 


\section{3 测定内容与方法}

\subsection{1产量及其构成因素成熟期调查每个小区} 100 穴, 计算有效穗数。取 10 穴调查每穗粒数、结 实率, 以 1000 粒实粒样本(干种子)称重, 重复 3 次 (误差不超过 $0.05 \mathrm{~g}$ ), 求取千粒重, 测理论产量。成 熟期从各小区割取 50 穴, 脱粒、去杂晒干后称重, 按照 $14.5 \%$ 水分含量换算出实际产量。

\subsection{2 稻米品质收获、脱粒、晒干并控制稻谷} 含水量为 $14.5 \%$ 。用 NP-4350 型风选机等风量风选, 参照中华人民共和国国家标准《GB/T17891-2017 优 质稻谷》测定䊁米率、精米率、整精米率、直链淀 粉含量、蛋白质含量、胶稠度。采用万深 SC-E 大米 外观品质检测仪测定精米的长和宽、长宽比、透明 度、严白粒率、严白面积比、严白度。采用澳大利 亚 Newport Scientific 仪器公司生产的 Super 3 型 RVA 快速黏度分析仪测定淀粉谱黏滞特性，用配套软件 TCW 分析。按照 AACC 规程(1995-61-02)和 RACI 标 准方法, 取含水量为 $14.00 \%$ 的米粉 $3.00 \mathrm{~g}$, 加蒸馏 水 $25.00 \mathrm{~g}$ 。在搅拌测定过程中, 罐内温度为 $50^{\circ} \mathrm{C}$, 保持 $1 \mathrm{~min}$ 后以 $11.84^{\circ} \mathrm{C} \mathrm{min}^{-1}$ 的速度上升到 $95^{\circ} \mathrm{C}$ (3.75 min)并保持 $2.5 \mathrm{~min}$, 再以 $11.84^{\circ} \mathrm{C} \mathrm{min}$ 的速度 下降到 $50^{\circ} \mathrm{C}$ 并保持 $1.4 \mathrm{~min}$ 。搅拌器在起始 $10 \mathrm{~s}$ 内转 动速度为 960 转 $\mathrm{min}^{-1}$, 之后保持在 160 转 $\mathrm{min}^{-1}$ 。
RVA 谱特征值包括峰值黏度、热浆黏度、最终黏度、 崩解值(峰值黏度-热浆黏度)、消减值(最终黏度一峰 值黏度)、回复值(最终黏度-热浆黏度)等。

\subsection{3 食味值指标采用米饭食味计(STA1A,} 日本佐竹公司)测定米饭的外观、硬度、黏度、平衡 值的评分和综合评分值。

1.3.4 温光资料 2017 年和 2018 年度间气候因 素无显著差异, 且该地区试验气象条件与常年一致, 具有代表性, 因此本文以 2017 年的气象数据作具体 分析，该年灌浆结实期间的平均温度、日照时数、 降雨量等资料取自安徽省淮南市凤台县气象站。

\section{4 统计分析}

采用 Microsoft Excel 2016 录入和计算 2017、 2018 两年的产量及其构成和品质数据, 使用 DPS 软 件作统计分析。

\section{2 结果与分析}

\section{1 不同年度粳稻产量及其食味值}

所选的 74 个常规粳稻品种中, 2017 年和 2018 年产量均超过 $5.5 \mathrm{t} \mathrm{hm}^{-2}$ (表 1), 产量均值大于 $7.50 \mathrm{t}$ $\mathrm{hm}^{-2}$, 标准差在 1 以内, 变异系数超过 $10 \%$; 食味值 在 40 74 之间, 食味值均值超过 50 分, 标准差接近 8 , 变异系数大于 $10 \%$ 。

\section{表 1 常规粳稻产量及其食味值}

Table 1 Yield and taste value in conventional japonica rice

\begin{tabular}{cccccc}
\hline $\begin{array}{c}\text { 年份 } \\
\text { Year }\end{array}$ & 指标 & $\begin{array}{c}\text { 变幅大小 } \\
\text { Index }\end{array}$ & $\begin{array}{c}\text { 均值 } \\
\text { Variable amplitude }\end{array}$ & $\begin{array}{c}\text { 标准差 } \\
\text { Standard deviation }\end{array}$ & $\begin{array}{c}\text { 变异系数 } \\
\text { CV }(\%)\end{array}$ \\
\hline \multirow{2}{*}{2017} & 食味值 Taste value & $40-71$ & 55 & 7.95 & 14.37 \\
& 产量 Yield $\left(\mathrm{t} \mathrm{hm}^{-2}\right)$ & $5.69-9.28$ & 7.67 & 0.77 & 10.05 \\
\multirow{2}{*}{2018} & 食味值 Taste value & $43-74$ & 57 & 7.84 & 12.48 \\
& 产量 Yield $\left(\mathrm{t} \mathrm{hm}^{-2}\right)$ & $5.51-9.21$ & 7.53 & 0.82 & 11.50 \\
\hline
\end{tabular}

2.2 不同类型常规粳稻的产量、食味值和生育期 根据 2017 年和 2018 年的产量和食味值, 通过 聚类分析, 可将供试的 74 个品种分为高产优质、高 产不优质、中产优质和中产不优质 4 种类型(表 2)。 在以上 4 种类型中, 筛选出生产上广泛应用并且符 合实际生产、市场需求的高产优质、高产不优质、 中产优质 3 种类型, 每个类型篮选出排序前 3 的品 种作为代表品种，对其产量及其构成因素、稻米品 质进行深入分析。

2.3 不同类型常规粳稻产量及其构成因素的差异 常规粳稻产量 2 年均表现为高产优质>高产不
优质>中产优质(表 3), 且中产优质类型与高产优质 类型、高产不优质类型有极显著差异, 2017 年和 2018 年, 中产优质类型产量较高产优质类型、高产不优质 类型分别低 $16.95 \% 、 16.76 \%$ 和 $16.52 \% 、 16.33 \%$; 单 位面积穗数表现为中产优质>高产不优质>高产优质, 高产类型与中产类型有显著差异; 高产优质类型与 中产优质类型在每穗粒数、结实率、千粒重上有极显 著或显著差异，且高产优质类型>中产优质，就 2017 年来看, 高产优质类型和高产不优质类型在每穗粒 数、结实率、千粒重上分别比中产优质类型高 $33.78 \% 、 3.18 \%$ 、5.34\%和 $32.23 \% 、 2.90 \% 、 3.04 \%$ 。 
表 2 不同类型常规粳稻产量、食味值和生育期的差异

Table 2 Yield and taste value and growth period in different types of conventional japonica rice

\begin{tabular}{|c|c|c|c|c|c|c|c|}
\hline \multirow{2}{*}{$\begin{array}{l}\text { 品种 } \\
\text { 类型 } \\
\text { Type }\end{array}$} & \multirow{2}{*}{$\begin{array}{c}\text { 品种 } \\
\text { 数量 } \\
\text { Number }\end{array}$} & \multirow{2}{*}{$\begin{array}{c}\text { 品种名称 } \\
\text { Cultivar }\end{array}$} & \multicolumn{2}{|c|}{ 食味值 Taste value } & \multicolumn{2}{|c|}{ 产量 Yield (t hm ${ }^{-2}$ ) } & \multirow{2}{*}{$\begin{array}{c}\text { 生育期 } \\
\text { Growth } \\
\text { period (d) }\end{array}$} \\
\hline & & & $\begin{array}{l}\text { 均值 } \\
\text { Mean }\end{array}$ & $\begin{array}{c}\text { 变幅 } \\
\text { Variable } \\
\text { amplitude }\end{array}$ & $\begin{array}{l}\text { 均值 } \\
\text { Mean }\end{array}$ & $\begin{array}{c}\text { 变幅 } \\
\text { Variable } \\
\text { amplitude }\end{array}$ & \\
\hline $\begin{array}{l}\text { 高产 } \\
\text { 优质 } \\
\text { HG }\end{array}$ & 16 & $\begin{array}{l}\text { 南粳 9108, 南粳 505, 南粳 5718, 宁 9039, 武 4610, } \\
\text { 常软 07-6, 常软 07-1, 南粳 2728, 镇稻 99, 徐稻 } 9 \\
\text { 号, 宁 9003, 宁 9022, 常软 07-4, 常软 07-3, 宁 } \\
5720 \text {, 常软 07-2 } \\
\text { Nanjing 9108, Nanjing 505, Nanjing 5718, Ning } \\
\text { 9039, Wu 4610, Changruan 07-6, Changruan 07-1, } \\
\text { Nanjing 2728, Zhendao 99, Xudao 9, Ning 9003, } \\
\text { Ning 9022, Changruan 07-4, Changruan 07-3, Ning } \\
5720 \text {, Changruan 07-2 }\end{array}$ & 65 & $60-74$ & 8.68 & $8.35-9.16$ & $150-160$ \\
\hline $\begin{array}{l}\text { 高产 } \\
\text { 不优质 } \\
\text { HB }\end{array}$ & 15 & $\begin{array}{l}\text { 武运 5051, 扬育粳 } 2 \text { 号, 扬粳 } 1612 \text {, 华粳 } 8 \text { 号, 连 } \\
\text { 粳 } 12 \text {, 宁粳 } 040 \text {, 泗 15-301, 华粳 } 5 \text { 号, 武运粳 } 21 \text {, } \\
\text { 镇 } 9471 \text {, 连粳 } 13 \text {, 连粳 13264, 苏秀 } 867 \text {, 连粳 } 15 \text {, } \\
\text { 武运 5020 } \\
\text { Wuyun 5051, Yangyujing 2, Yangjing 1612, Huajing } \\
\text { 8, Lianjing 12, Ningjing 040, Si 15-301, Huajing 5, } \\
\text { Wuyunjing 21, Zhen 9471, Lianjing 13, Lianjing } \\
\text { 13264, Suxiu 867, Lianjing 15, Wuyun 5020 }\end{array}$ & 53 & $45-59$ & 8.60 & $8.24-9.28$ & $140-160$ \\
\hline $\begin{array}{l}\text { 中产 } \\
\text { 优质 } \\
\text { MG }\end{array}$ & 11 & $\begin{array}{l}\text { 宁粳 } 7 \text { 号, 宁粳 } 4 \text { 号, 淮稻 } 5 \text { 号, 常软 } 07-5 \text {, 福粳 } \\
1606 \text {, 沪香粳 } 165 \text {, 南繁 } 1610 \text {, 南繁 } 1605 \text {, 泗 } \\
\text { 15-234, 苏香粳 } 3 \text { 号, 松早香 } 1 \text { 号 } \\
\text { Ningjing } 7 \text {, Ningjing 4, Huaidao 5, Changruan } 07-5 \text {, } \\
\text { Fujing 1606, Huxiangjing } 165 \text {, Nanfan } 1610, \text { Nanfan } \\
\text { 1605, Si 15-234, Suxiangjing 3, Songzaoxiang } 1\end{array}$ & 65 & $63-69$ & 7.57 & $6.88-8.05$ & $135-155$ \\
\hline $\begin{array}{l}\text { 中产 } \\
\text { 不优质 } \\
\text { MB }\end{array}$ & 32 & 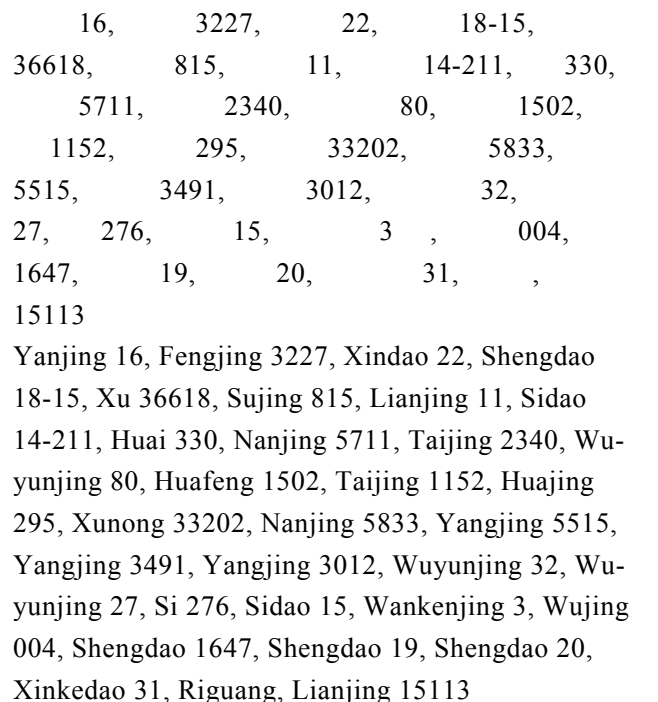 & 50 & $40-59$ & 7.25 & $5.51-7.96$ & $135-155$ \\
\hline
\end{tabular}

HG: high yield with good quality; HB: high yield with bad quality; MG: medium yield with good quality; MB: medium yield with bad quality.

\section{4 不同类型常规粳稻食味值的差异} 就 2017 年来看, 常规粳稻的食味值表现为高产 优质>中产优质>高产不优质(表 4), 高产优质类型、
中产优质类型的食味值分别比高产不优质类型高出 $18.64 \% 、 16.95 \%$, 差异极显著; 在外观、硬度、平 衡度上与高产不优质类型均表现出极显著差异; 在 
表 3 不同类型常规粳稻的产量及其构成因素

Table 3 Yield and components in different types of conventional japonica rice

\begin{tabular}{|c|c|c|c|c|c|c|}
\hline $\begin{array}{c}\text { 品种类型 } \\
\text { Type }\end{array}$ & $\begin{array}{c}\text { 品种名称 } \\
\text { Cultivar }\end{array}$ & $\begin{array}{c}\text { 单位面积穗数 } \\
\text { No. of panicles } \\
\left(\times 10^{4} \mathrm{hm}^{-2}\right)\end{array}$ & $\begin{array}{c}\text { 每穗粒数 } \\
\text { Spikelets per } \\
\text { panicle }\end{array}$ & $\begin{array}{c}\text { 结实率 } \\
\text { Seed-setting } \\
\text { rate }(\%)\end{array}$ & $\begin{array}{c}\text { 千粒重 } \\
\text { 1000-grain } \\
\text { weight }(\mathrm{g})\end{array}$ & $\begin{array}{c}\text { 产量 } \\
\text { Yield } \\
\left(\mathrm{t} \mathrm{hm}^{-2}\right)\end{array}$ \\
\hline \multicolumn{7}{|l|}{2017} \\
\hline 高产优质 & 南粳 9108 Nanjing 9108 & 318.20 & 139.98 & 86.80 & 25.13 & 9.08 \\
\hline \multirow[t]{3}{*}{$\mathrm{HG}$} & 南粳 505 Nanjing 505 & 314.80 & 139.49 & 84.61 & 25.28 & 8.89 \\
\hline & 徐稻 9 号 Xudao 9 & 316.40 & 140.32 & 83.69 & 25.40 & 8.93 \\
\hline & 平均值 Mean & $316.47 \mathrm{Ab}$ & $139.93 \mathrm{Aa}$ & $85.03 \mathrm{Aa}$ & $25.27 \mathrm{Aa}$ & $8.97 \mathrm{Aa}$ \\
\hline 高产不优质 & 武运 5051 Wuyun 5051 & 320.40 & 140.33 & 84.91 & 24.58 & 8.80 \\
\hline \multirow[t]{3}{*}{$\mathrm{HB}$} & 扬粳 1612 Yangjing 1612 & 323.50 & 138.26 & 85.67 & 24.30 & 8.99 \\
\hline & 华粳 8 号 Huajing 8 & 324.10 & 136.34 & 83.81 & 25.28 & 9.05 \\
\hline & 平均值 Mean & $322.67 \mathrm{Ab}$ & $138.31 \mathrm{Aa}$ & $84.80 \mathrm{Aa}$ & $24.72 \mathrm{Aab}$ & $8.95 \mathrm{Aa}$ \\
\hline 中产优质 & 福粳 1606 Fujing 1606 & 345.00 & 112.80 & 82.47 & 23.50 & 7.54 \\
\hline \multirow[t]{3}{*}{ MG } & 苏香粳 3 号 Suxiangjing 3 & 396.55 & 91.50 & 82.39 & 23.53 & 7.03 \\
\hline & 松早香 1 号 Songzaoxiang 1 & 346.80 & 109.50 & 82.38 & 24.93 & 7.79 \\
\hline & 平均值 Mean & $362.78 \mathrm{Aa}$ & $104.60 \mathrm{Bb}$ & $82.41 \mathrm{Ab}$ & $23.99 \mathrm{Ab}$ & $7.45 \mathrm{Bb}$ \\
\hline \multicolumn{7}{|l|}{2018} \\
\hline 高产优质 & 南粳 9108 Nanjing 9108 & 319.20 & 138.78 & 86.20 & 25.85 & 9.15 \\
\hline \multirow[t]{3}{*}{ HG } & 南粳 505 Nanjing 505 & 310.75 & 137.00 & 85.53 & 25.90 & 8.98 \\
\hline & 徐稻 9 号 Xudao 9 & 311.45 & 138.02 & 85.46 & 25.25 & 8.93 \\
\hline & 平均值 Mean & $313.80 \mathrm{Ab}$ & $137.93 \mathrm{Aa}$ & $85.73 \mathrm{Aa}$ & $25.67 \mathrm{Aa}$ & $9.02 \mathrm{Aa}$ \\
\hline 高产不优质 & 武运 5051 Wuyun 5051 & 315.50 & 137.17 & 85.30 & 24.83 & 8.92 \\
\hline \multirow[t]{3}{*}{ HB } & 扬粳 1612 Yangjing 1612 & 319.20 & 137.95 & 84.82 & 25.35 & 9.02 \\
\hline & 华粳 8 号 Huajing 8 & 316.45 & 136.44 & 85.90 & 25.55 & 9.05 \\
\hline & 平均值 Mean & $317.05 \mathrm{Ab}$ & $137.19 \mathrm{Aa}$ & $85.34 \mathrm{Aa}$ & $25.24 \mathrm{Aab}$ & $9.00 \mathrm{Aa}$ \\
\hline 中产优质 & 福粳 1606 Fujing 1606 & 348.70 & 113.46 & 81.96 & 23.90 & 7.72 \\
\hline \multirow[t]{3}{*}{ MG } & 苏香粳 3 号 Suxiangjing 3 & 385.70 & 94.00 & 83.68 & 23.73 & 7.22 \\
\hline & 松早香 1 号 Songzaoxiang 1 & 345.25 & 107.00 & 83.46 & 24.80 & 7.64 \\
\hline & 平均值 Mean & $359.88 \mathrm{Aa}$ & $104.82 \mathrm{Bb}$ & $83.03 \mathrm{Ab}$ & $24.14 \mathrm{Ab}$ & $7.53 \mathrm{Bb}$ \\
\hline
\end{tabular}

同一品种同列数据后不同小、大写字母分别表示处理间差异达 $5 \%$ 和 $1 \%$ 显著水平。缩写同表 2 。

Values for a cultivar within a column followed by different lowercase and capital letters are significantly different at the $5 \%$ and $1 \%$ probability levels, respectively. Abbreviations are the same as those given in Table 2 .

外观上分别比高产不优质类型高出 $34.00 \% 、 36.00 \%$; 在黏度和平衡度上, 分别比高产不优质类型高出 $33.33 \% 、 27.45 \%$ 和 $37.5 \% 、 35.42 \%$; 硬度比高产不 优质类型均高出 $12.12 \%$ 。对应类型品种食味值各指 标在不同年度间都无显著差异。

\section{5 不同类型常规粳稻加工品质的差异}

2017 年, 䊁米率和精米率都表现为高产优质类 型>中产优质>高产不优质(表 5), 但都无显著差异, 且高产优质类型、中产优质类型分别比高产不优质 类型高出 $1.48 \% 、 1.18 \%$ 和 $1.23 \% 、 2.30 \%$; 高产不优 质类型的整精米率要高于高产优质类型和中产优质
类型，并与中产优质类型有显著差异。对应类型品 种加工品质各指标在不同年度间无显著差异。

\section{6 不同类型常规粳稻外观品质的差异}

2017 年, 在透明度等级指标上, 优质类型高于 不优质类型(表 6), 长宽比表现为中产优质>高产不 优质>高产优质，在透明度等级、长宽比上，各类型 间都无显著差异; 严白率表现为高产优质>中产优 质>高产不优质, 优质类型与不优质类型有显著差 异, 严白度在高产优质类型与高产不优质类型之间 有显著差异。对应类型品种外观品质各指标在不同 年度间无显著差异。 
表 4 不同类型常规粳稻的食味值

Table 4 Taste value in different types of conventional japonica rice

\begin{tabular}{|c|c|c|c|c|c|c|}
\hline $\begin{array}{c}\text { 品种类型 } \\
\text { Type }\end{array}$ & $\begin{array}{c}\text { 品种名称 } \\
\text { Cultivar }\end{array}$ & $\begin{array}{c}\text { 食味值 } \\
\text { Taste value }\end{array}$ & $\begin{array}{c}\text { 外观 } \\
\text { Appearance }\end{array}$ & $\begin{array}{c}\text { 硬度 } \\
\text { Hardness }\end{array}$ & $\begin{array}{c}\text { 黏度 } \\
\text { Viscosity }\end{array}$ & $\begin{array}{c}\text { 平衡度 } \\
\text { Balance degree }\end{array}$ \\
\hline \multicolumn{7}{|l|}{2017} \\
\hline \multirow{4}{*}{$\begin{array}{l}\text { 高产优质 } \\
\text { HG }\end{array}$} & 南粳 9108 Nanjing 9108 & 71 & 6.8 & 6.5 & 6.9 & 6.7 \\
\hline & 南粳 505 Nanjing 505 & 69 & 6.7 & 6.7 & 6.5 & 6.4 \\
\hline & 徐稻 9 号 Xudao 9 & 71 & 6.7 & 6.6 & 7.1 & 6.8 \\
\hline & 平均值 Mean & $70 \mathrm{Aa}$ & $6.7 \mathrm{Aa}$ & $6.6 \mathrm{Bb}$ & $6.8 \mathrm{Aa}$ & $6.6 \mathrm{Aa}$ \\
\hline \multirow{4}{*}{$\begin{array}{l}\text { 高产不优质 } \\
\text { HB }\end{array}$} & 武运 5051 Wuyun 5051 & 58 & 5.3 & 7.2 & 4.5 & 4.7 \\
\hline & 扬粳 1612 Yangjing 1612 & 60 & 4.9 & 7.5 & 5.5 & 4.9 \\
\hline & 华粳 8 号 Huajing 8 & 59 & 4.9 & 7.5 & 5.4 & 4.9 \\
\hline & 平均值 Mean & $59 \mathrm{Bb}$ & $5.0 \mathrm{Bb}$ & 7.4 Aa & $5.1 \mathrm{Ab}$ & $4.8 \mathrm{Bb}$ \\
\hline \multirow{4}{*}{$\begin{array}{l}\text { 中产优质 } \\
\text { MG }\end{array}$} & 福粳 1606 Fujing 1606 & 69 & 6.8 & 6.6 & 6.4 & 6.4 \\
\hline & 苏香粳 3 号 Suxiangjing 3 & 71 & 7.0 & 6.5 & 7.3 & 7.1 \\
\hline & 松早香 1 号 Songzaoxiang 1 & 67 & 6.5 & 6.6 & 5.9 & 6.1 \\
\hline & 平均值 Mean & $69 \mathrm{Aa}$ & $6.8 \mathrm{Aa}$ & $6.6 \mathrm{Bb}$ & $6.5 \mathrm{Aa}$ & $6.5 \mathrm{Aa}$ \\
\hline \multicolumn{7}{|l|}{2018} \\
\hline \multirow{4}{*}{$\begin{array}{l}\text { 高产优质 } \\
\text { HG }\end{array}$} & 南粳 9108 Nanjing 9108 & 68 & 6.3 & 6.8 & 6.5 & 6.3 \\
\hline & 南粳 505 Nanjing 505 & 73 & 7.0 & 6.3 & 6.9 & 7.4 \\
\hline & 徐稻 9 号 Xudao 9 & 71 & 6.5 & 6.5 & 6.8 & 7.2 \\
\hline & 平均值 Mean & $71 \mathrm{Aa}$ & 6.6 Aa & $6.5 \mathrm{Bb}$ & $6.7 \mathrm{Aa}$ & 7.0 Aa \\
\hline \multirow{4}{*}{$\begin{array}{l}\text { 高产不优质 } \\
\mathrm{HB}\end{array}$} & 武运 5051 Wuyun 5051 & 57 & 5.5 & 7.5 & 4.8 & 4.7 \\
\hline & 扬粳 1612 Yangjing 1612 & 59 & 5.4 & 7.3 & 5.8 & 4.5 \\
\hline & 华粳 8 号 Huajing 8 & 57 & 4.9 & 7.5 & 5.4 & 4.5 \\
\hline & 平均值 Mean & $58 \mathrm{Bb}$ & $5.3 \mathrm{Bb}$ & 7.4 Aa & $5.3 \mathrm{Ab}$ & 4.6 Bb \\
\hline 中产优质 & 福粳 1606 Fujing 1606 & 68 & 6.3 & 6.9 & 6.6 & 6.2 \\
\hline \multirow[t]{3}{*}{ MG } & 苏香粳 3 号 Suxiangjing 3 & 69 & 6.9 & 6.7 & 7.2 & 6.9 \\
\hline & 松早香 1 号 Songzaoxiang 1 & 71 & 6.7 & 6.7 & 5.9 & 6.8 \\
\hline & 平均值 Mean & $69 \mathrm{Aa}$ & $6.6 \mathrm{Aa}$ & $6.8 \mathrm{Bb}$ & $6.6 \mathrm{Aa}$ & $6.6 \mathrm{Aa}$ \\
\hline \multicolumn{2}{|c|}{ 年度间 Between years } & ns & ns & ns & ns & $\mathrm{ns}$ \\
\hline
\end{tabular}

同一品种同列数据后不同小、大写字母分别表示处理间差异达 $5 \%$ 和 $1 \%$ 显著水平。ns 表示差异不显著。缩写同表 2 。

Values for a cultivar within a column followed by different lowercase and capital letters are significantly different at the $5 \%$ and $1 \%$ probability levels, respectively. ns: not significant. Abbreviations are the same as those given in Table 2 .

\section{7 不同类型常规粳稻营养品质及蒸煮食味品} 质的差异

2017 年, 高产不优质类型常规粳稻的直链淀粉 含量高于高产优质类型、中产优质类型(表 7), 分别 高出 $39.31 \%$ 、 $42.63 \%$, 优质类型与不优质类型有显 著差异; 胶稠度表现为高产优质>中产优质>高产不 优质，高产优质类型、中产优质类型的胶稠度分别 比高产不优质类型长 $22.06 \%$ 、19.12\%, 优质类型与 不优质类型有极显著差异; 高产优质类型、中产优
质类型的蛋白质含量比高产不优质类型分别低 $7.31 \% 、 4.79 \%$ ，高产优质类型与高产不优质类型有 显著差异。对应类型品种营养和蒸煮食味品质各指 标在不同年度间无显著差异。

\section{8 不同类型常规粳稻 RVA 谱特征值的差异}

就 2017 年而言, 不同类型常规粳稻品种的峰值 黏度、热浆黏度、最终黏度之间均表现为中产优质> 高产不优质>高产优质(表 8); 优质类型的崩解值高 于不优质类型, 差异显著, 而消减值和回复值低于 
表 5 不同类型常规粳稻的加工品质

Table 5 Processing quality in different types of conventional japonica rice (\%)

\begin{tabular}{|c|c|c|c|c|}
\hline $\begin{array}{c}\text { 品种类型 } \\
\text { Type } \\
\end{array}$ & $\begin{array}{c}\text { 品种名称 } \\
\text { Cultivar }\end{array}$ & $\begin{array}{c}\text { 糙米率 } \\
\text { Brown rice rate }\end{array}$ & $\begin{array}{c}\text { 精米率 } \\
\text { Milled rice rate }\end{array}$ & $\begin{array}{c}\text { 整精米率 } \\
\text { Head milled rice rate }\end{array}$ \\
\hline \multicolumn{5}{|l|}{2017} \\
\hline \multirow{4}{*}{$\begin{array}{l}\text { 高产优质 } \\
\text { HG }\end{array}$} & 南粳 9108 Nanjing 9108 & 85.58 & 69.56 & 64.29 \\
\hline & 南粳 505 Nanjing 505 & 82.86 & 66.19 & 62.09 \\
\hline & 徐稻 9 号 Xudao 9 & 84.28 & 71.62 & 59.54 \\
\hline & 平均值 Mean & $84.24 \mathrm{Aa}$ & $69.12 \mathrm{Aa}$ & $61.97 \mathrm{Aab}$ \\
\hline \multirow{4}{*}{$\begin{array}{l}\text { 高产不优质 } \\
\mathrm{HB}\end{array}$} & 武运 5051 Wuyun 5051 & 82.24 & 64.69 & 63.19 \\
\hline & 扬粳 1612 Yangjing 1612 & 83.47 & 68.06 & 61.76 \\
\hline & 华粳 8 号 Huajing 8 & 83.33 & 72.09 & 64.38 \\
\hline & 平均值 Mean & $83.01 \mathrm{Aa}$ & $68.28 \mathrm{Aa}$ & $63.11 \mathrm{Aa}$ \\
\hline \multirow{4}{*}{$\begin{array}{l}\text { 中产优质 } \\
\mathrm{MG}\end{array}$} & 福粳 1606 Fujing 1606 & 83.25 & 69.58 & 58.80 \\
\hline & 苏香粳 3 号 Suxiangjing 3 & 84.68 & 69.39 & 60.03 \\
\hline & 松早香 1 号 Songzaoxiang 1 & 84.03 & 70.58 & 57.12 \\
\hline & 平均值 Mean & $83.99 \mathrm{Aa}$ & $69.85 \mathrm{Aa}$ & $58.65 \mathrm{Ab}$ \\
\hline \multicolumn{5}{|l|}{2018} \\
\hline \multirow{4}{*}{$\begin{array}{l}\text { 高产优质 } \\
\mathrm{HG}\end{array}$} & 南粳 9108 Nanjing 9108 & 84.93 & 70.94 & 64.06 \\
\hline & 南粳 505 Nanjing 505 & 83.22 & 66.70 & 62.37 \\
\hline & 徐稻 9 号 Xudao 9 & 84.28 & 69.75 & 60.13 \\
\hline & 平均值 Mean & $84.14 \mathrm{Aa}$ & $69.13 \mathrm{Aa}$ & $62.19 \mathrm{Aab}$ \\
\hline \multirow{4}{*}{$\begin{array}{l}\text { 高产不优质 } \\
\mathrm{HB}\end{array}$} & 武运 5051 Wuyun 5051 & 82.68 & 66.63 & 62.67 \\
\hline & 扬粳 1612 Yangjing 1612 & 83.64 & 66.88 & 62.01 \\
\hline & 华粳 8 号 Huajing 8 & 83.50 & 70.30 & 63.53 \\
\hline & 平均值 Mean & $83.27 \mathrm{Aa}$ & $67.94 \mathrm{Aa}$ & $62.74 \mathrm{Aa}$ \\
\hline \multirow{4}{*}{$\begin{array}{l}\text { 中产优质 } \\
\mathrm{MG}\end{array}$} & 福粳 1606 Fujing 1606 & 84.66 & 70.65 & 58.98 \\
\hline & 苏香粳 3 号 Suxiangjing 3 & 83.56 & 70.53 & 60.27 \\
\hline & 松早香 1 号 Songzaoxiang 1 & 83.50 & 71.04 & 57.96 \\
\hline & 平均值 Mean & $83.91 \mathrm{Aa}$ & $70.74 \mathrm{Aa}$ & $59.07 \mathrm{Ab}$ \\
\hline \multicolumn{2}{|c|}{ 年度间 Between years } & $\mathrm{ns}$ & $\mathrm{ns}$ & $\mathrm{ns}$ \\
\hline
\end{tabular}

同一品种同列数据后不同小、大写字母分别表示处理间差异达 $5 \%$ 和 $1 \%$ 显著水平。ns 表示差异不显著。缩写同表 2 。

Values for a cultivar within a column followed by different lowercase and capital letters are significantly different at the $5 \%$ and $1 \%$ probability levels, respectively. ns: not significant. Abbreviations are the same as those given in Table 2.

不优质类型，差异显著或极显著。对应类型品种 $\mathrm{RVA}$ 谱特征值在不同年度间无显著差异。

\subsection{7 年不同类型常规粳稻生育期及灌浆结} 实期温光差异

灌浆结实天数表现为高产不优质 $>$ 高产优质 $>$ 中 产优质(表 9), 高产不优质类型比中产优质类型多 10 $\mathrm{d} ，$ 比高产优质类型多 $3 \mathrm{~d}$; 灌浆结实期天数在高产 不优质类型与中产优质类型之间有显著差异; 灌浆 结实期的温光, 降雨量、积温、日照时数均表现为 高产不优质>高产优质>中产优质, 高产不优质类型 与中产优质类型在积温、日照时数和降水量上都表 现出显著差异。 
表 6 不同类型常规粳稻的外观品质

Table 6 Appearance quality in different types of conventional japonica rice

\begin{tabular}{|c|c|c|c|c|c|}
\hline $\begin{array}{c}\text { 品种类型 } \\
\text { Type }\end{array}$ & $\begin{array}{c}\text { 品种名称 } \\
\text { Cultivar }\end{array}$ & $\begin{array}{c}\text { 透明度 } \\
\text { Transparency }\end{array}$ & $\begin{array}{c}\text { 长宽比 } \\
\text { Length-width ratio }\end{array}$ & $\begin{array}{c}\text { 严白率 } \\
\text { Chalkiness rate } \\
(\%)\end{array}$ & $\begin{array}{c}\text { 严白度 } \\
\text { Chalkiness degree } \\
(\%)\end{array}$ \\
\hline \multicolumn{6}{|l|}{2017} \\
\hline \multirow{4}{*}{$\begin{array}{l}\text { 高产优质 } \\
\text { HG }\end{array}$} & 南粳 9108 Nanjing 9108 & 3 & 1.67 & 64.95 & 23.30 \\
\hline & 南粳 505 Nanjing 505 & 4 & 1.75 & 59.82 & 21.86 \\
\hline & 徐稻 9 号 Xudao 9 & 2 & 1.83 & 42.57 & 19.57 \\
\hline & 平均值 Mean & $3 \mathrm{Aa}$ & $1.75 \mathrm{Aa}$ & $55.78 \mathrm{Aa}$ & $21.58 \mathrm{Aa}$ \\
\hline \multirow{4}{*}{$\begin{array}{l}\text { 高产不优质 } \\
\text { HB }\end{array}$} & 武运 5051 Wuyun 5051 & 3 & 1.76 & 49.46 & 18.73 \\
\hline & 扬粳 1612 Yangjing 1612 & 2 & 1.75 & 47.95 & 16.24 \\
\hline & 华粳 8 号 Huajing 8 & 2 & 1.93 & 22.73 & 8.15 \\
\hline & 平均值 Mean & $2 \mathrm{Aa}$ & $1.81 \mathrm{Aa}$ & $40.05 \mathrm{Ab}$ & $14.37 \mathrm{Ab}$ \\
\hline \multirow{4}{*}{$\begin{array}{l}\text { 中产优质 } \\
\mathrm{MG}\end{array}$} & 福粳 1606 Fujing 1606 & 3 & 1.70 & 45.02 & 18.68 \\
\hline & 苏香粳 3 号 Suxiangjing 3 & 4 & 2.03 & 66.85 & 23.75 \\
\hline & 松早香 1 号 Songzaoxiang 1 & 3 & 2.35 & 49.31 & 18.77 \\
\hline & 平均值 Mean & $3 \mathrm{Aa}$ & $2.03 \mathrm{Aa}$ & $53.73 \mathrm{Aa}$ & $20.40 \mathrm{Aab}$ \\
\hline \multicolumn{6}{|l|}{2018} \\
\hline \multirow{4}{*}{$\begin{array}{l}\text { 高产优质 } \\
\text { HG }\end{array}$} & 南粳 9108 Nanjing 9108 & 3 & 1.71 & 67.05 & 25.80 \\
\hline & 南粳 505 Nanjing 505 & 5 & 1.74 & 61.86 & 22.85 \\
\hline & 徐稻 9 号 Xudao 9 & 3 & 1.89 & 42.83 & 20.34 \\
\hline & 平均值 Mean & $4 \mathrm{Aa}$ & $1.78 \mathrm{Aa}$ & $57.25 \mathrm{Aa}$ & $23.00 \mathrm{Aa}$ \\
\hline \multirow{4}{*}{$\begin{array}{l}\text { 高产不优质 } \\
\text { HB }\end{array}$} & 武运 5051 Wuyun 5051 & 4 & 1.76 & 46.63 & 18.87 \\
\hline & 扬粳 1612 Yangjing 1612 & 3 & 1.73 & 46.28 & 19.79 \\
\hline & 华粳 8 号 Huajing 8 & 2 & 1.92 & 21.57 & 8.43 \\
\hline & 平均值 Mean & $3 \mathrm{Aa}$ & $1.80 \mathrm{Aa}$ & $38.16 \mathrm{Ab}$ & $15.70 \mathrm{Ab}$ \\
\hline \multirow{4}{*}{$\begin{array}{l}\text { 中产优质 } \\
\text { MG }\end{array}$} & 福粳 1606 Fujing 1606 & 2 & 1.76 & 49.92 & 20.47 \\
\hline & 苏香粳 3 号 Suxiangjing 3 & 4 & 2.11 & 66.21 & 25.85 \\
\hline & 松早香 1 号 Songzaoxiang 1 & 4 & 2.32 & 48.73 & 19.26 \\
\hline & 平均值 Mean & $3 \mathrm{Aa}$ & $2.06 \mathrm{Aa}$ & $54.95 \mathrm{Aa}$ & $21.86 \mathrm{Aab}$ \\
\hline \multicolumn{2}{|c|}{ 年度间 Between years } & ns & $\mathrm{ns}$ & $\mathrm{ns}$ & $\mathrm{ns}$ \\
\hline
\end{tabular}

同一品种同列数据后不同小、大写字母分别表示处理间差异达 $5 \%$ 和 $1 \%$ 显著水平。ns 表示差异不显著。缩写同表 2 。

Values for a cultivar within a column followed by different lowercase and capital letters are significantly different at the $5 \%$ and $1 \%$ probability levels, respectively. ns: not significant. Abbreviations are the same as those given in Table 2.

表 7 不同类型常规粳稻的营养品质及蒸煮食味品质

Table 7 Nutritional, cooking and eating quality in different types of conventional japonica rice

\begin{tabular}{ccccc}
\hline $\begin{array}{c}\text { 品种类型 } \\
\text { Type }\end{array}$ & $\begin{array}{c}\text { 品种名称 } \\
\text { Cultivar }\end{array}$ & $\begin{array}{c}\text { 直链淀粉含量 } \\
\text { Amylose content }(\%)\end{array}$ & $\begin{array}{c}\text { 胶稠度 } \\
\text { Gel consistency (mm) }\end{array}$ & $\begin{array}{c}\text { 蛋白质含量 } \\
\text { Protein content (\%) }\end{array}$ \\
\hline 2017 & & & & \\
高产优质 & 南粳 9108 Nanjing 9108 & 10.49 & 87 & 7.59 \\
HG & 南粳 505 Nanjing 505 & 10.43 & 82 & 7.05 \\
\hline
\end{tabular}


(续表 7)

\begin{tabular}{|c|c|c|c|c|}
\hline $\begin{array}{c}\text { 品种类型 } \\
\text { Type } \\
\end{array}$ & $\begin{array}{l}\text { 品种名称 } \\
\text { Cultivar } \\
\end{array}$ & $\begin{array}{c}\text { 直链淀粉含量 } \\
\text { Amylose content }(\%)\end{array}$ & $\begin{array}{c}\text { 胶稠度 } \\
\text { Gel consistency }(\mathrm{mm})\end{array}$ & $\begin{array}{c}\text { 蛋白质含量 } \\
\text { Protein content (\%) }\end{array}$ \\
\hline & 徐稻 9 号 Xudao 9 & 13.87 & 81 & 7.40 \\
\hline & 平均值 Mean & $11.60 \mathrm{Ab}$ & $83 \mathrm{Aa}$ & $7.35 \mathrm{Ab}$ \\
\hline 高产不优质 & 武运 5051 Wuyun 5051 & 14.17 & 67 & 7.99 \\
\hline \multirow[t]{3}{*}{ HB } & 扬粳 1612 Yangjing 1612 & 16.32 & 71 & 7.64 \\
\hline & 华粳 8 号 Huajing 8 & 18.00 & 66 & 8.16 \\
\hline & 平均值 Mean & $16.16 \mathrm{Aa}$ & $68 \mathrm{Bb}$ & $7.93 \mathrm{Aa}$ \\
\hline 中产优质 & 福粳 1606 Fujing 1606 & 11.51 & 81 & 7.55 \\
\hline \multirow[t]{3}{*}{ MG } & 苏香粳 3 号 Suxiangjing 3 & 11.75 & 78 & 7.69 \\
\hline & 松早香 1 号 Songzaoxiang 1 & 10.72 & 83 & 7.21 \\
\hline & 平均值 Mean & $11.33 \mathrm{Ab}$ & $81 \mathrm{Aa}$ & 7.55 Aab \\
\hline \multicolumn{5}{|l|}{2018} \\
\hline 高产优质 & 南粳 9108 Nanjing 9108 & 10.47 & 89 & 7.43 \\
\hline \multirow[t]{3}{*}{$\mathrm{HG}$} & 南粳 505 Nanjing 505 & 10.41 & 83 & 7.04 \\
\hline & 徐稻 9 号 Xudao 9 & 13.67 & 81 & 7.34 \\
\hline & 平均值 Mean & $11.52 \mathrm{Ab}$ & $84 \mathrm{Aa}$ & $7.27 \mathrm{Ab}$ \\
\hline 高产不优质 & 武运 5051 Wuyun 5051 & 13.91 & 65 & 7.90 \\
\hline \multirow[t]{3}{*}{ HB } & 扬粳 1612 Yangjing 1612 & 16.42 & 68 & 7.59 \\
\hline & 华粳 8 号 Huajing 8 & 17.84 & 65 & 8.10 \\
\hline & 平均值 Mean & $16.06 \mathrm{Aa}$ & $66 \mathrm{Bb}$ & $7.86 \mathrm{Aa}$ \\
\hline 中产优质 & 福粳 1606 Fujing 1606 & 11.20 & 80 & 7.69 \\
\hline \multirow[t]{3}{*}{ MG } & 苏香粳 3 号 Suxiangjing 3 & 11.51 & 78 & 7.83 \\
\hline & 松早香 1 号 Songzaoxiang 1 & 10.82 & 82 & 7.56 \\
\hline & 平均值 Mean & $11.18 \mathrm{Ab}$ & $80 \mathrm{Aa}$ & 7.69 Aab \\
\hline 年度间 Between years & & $\mathrm{ns}$ & $\mathrm{ns}$ & ns \\
\hline
\end{tabular}

同一品种同列数据后不同小、大写字母分别表示处理间差异达 $5 \%$ 和 $1 \%$ 显著水平。ns 表示差异不显著。缩写同表 2 。

Values for a cultivar within a column followed by different lowercase and capital letters are significantly different at the $5 \%$ and $1 \%$ probability levels, respectively. ns: not significant. Abbreviations are the same as those given in Table 2 .

表 8 不同类型常规粳稻的 RVA 谱特征值

Table 8 RVA profile characteristics in different types of conventional japonica rice (cP)

\begin{tabular}{|c|c|c|c|c|c|c|c|}
\hline $\begin{array}{c}\text { 品种类型 } \\
\text { Type } \\
\end{array}$ & $\begin{array}{l}\text { 品种名称 } \\
\text { Cultivar }\end{array}$ & $\begin{array}{c}\text { 峰值黏度 } \\
\text { Peak viscosity }\end{array}$ & $\begin{array}{c}\text { 热浆黏度 } \\
\text { Trough viscosity }\end{array}$ & $\begin{array}{c}\text { 最终黏度 } \\
\text { Final viscosity }\end{array}$ & $\begin{array}{c}\text { 崩解值 } \\
\text { Breakdown }\end{array}$ & $\begin{array}{l}\text { 消减值 } \\
\text { Setback }\end{array}$ & $\begin{array}{c}\text { 回复值 } \\
\text { Consistence } \\
\end{array}$ \\
\hline \multicolumn{8}{|l|}{2017} \\
\hline 高产优质 & 南粳 9108 Nanjing 9108 & 2109 & 957 & 1729 & 1152 & -380 & 772 \\
\hline \multirow[t]{3}{*}{ HG } & 南粳 505 Nanjing 505 & 2143 & 1066 & 1673 & 1077 & -470 & 607 \\
\hline & 徐稻 9 号 Xudao 9 & 2244 & 1251 & 2037 & 993 & -207 & 786 \\
\hline & 平均值 Mean & $2165 \mathrm{Bb}$ & $1091 \mathrm{Bc}$ & $1813 \mathrm{Bb}$ & $1074 \mathrm{Aa}$ & $-352 \mathrm{Bb}$ & $722 \mathrm{Bc}$ \\
\hline 高产不优质 & 武运 5051 Wuyun 5051 & 2315 & 1408 & 2452 & 907 & 137 & 1044 \\
\hline \multirow[t]{3}{*}{$\mathrm{HB}$} & 扬粳 1612 Yangjing 1612 & 2350 & 1464 & 2475 & 886 & 125 & 1011 \\
\hline & 华粳 8 号 Huajing 8 & 2245 & 1405 & 2455 & 840 & 210 & 1050 \\
\hline & 平均值 Mean & $2303 \mathrm{ABb}$ & $1426 \mathrm{ABb}$ & $2461 \mathrm{Aa}$ & $878 \mathrm{Ab}$ & $157 \mathrm{Aa}$ & $1035 \mathrm{Aa}$ \\
\hline 中产优质 & 福粳 1606 Fujing 1606 & 2872 & 1695 & 2665 & 1177 & -207 & 970 \\
\hline \multirow[t]{3}{*}{$\mathrm{MG}$} & 苏香粳 3 号 Suxiangjing 3 & 2600 & 1656 & 2495 & 944 & -105 & 839 \\
\hline & 松早香 1 号 Songzaoxiang 1 & 2623 & 1628 & 2445 & 995 & -178 & 817 \\
\hline & 平均值 Mean & $2698 \mathrm{Aa}$ & $1660 \mathrm{Aa}$ & $2535 \mathrm{Aa}$ & $1039 \mathrm{Aa}$ & $-163 \mathrm{Bb}$ & $875 \mathrm{ABb}$ \\
\hline
\end{tabular}


(续表 8)

\begin{tabular}{|c|c|c|c|c|c|c|c|}
\hline $\begin{array}{c}\text { 品种类型 } \\
\text { Type } \\
\end{array}$ & $\begin{array}{c}\text { 品种名称 } \\
\text { Cultivar }\end{array}$ & $\begin{array}{c}\text { 峰值黏度 } \\
\text { Peak viscosity }\end{array}$ & $\begin{array}{c}\text { 热浆黏度 } \\
\text { Trough viscosity }\end{array}$ & $\begin{array}{c}\text { 最终黏度 } \\
\text { Final viscosity }\end{array}$ & $\begin{array}{c}\text { 崩解值 } \\
\text { Breakdown } \\
\end{array}$ & $\begin{array}{l}\text { 消减值 } \\
\text { Setback }\end{array}$ & $\begin{array}{c}\text { 回复值 } \\
\text { Consistence } \\
\end{array}$ \\
\hline \multicolumn{8}{|l|}{2018} \\
\hline 高产优质 & 南粳 9108 Nanjing 9108 & 1910 & 797 & 1618 & 1113 & -292 & 821 \\
\hline \multirow[t]{3}{*}{ HG } & 南粳 505 Nanjing 505 & 2449 & 1319 & 1774 & 1130 & -575 & 555 \\
\hline & 徐稻 9 号 Xudao 9 & 2413 & 1536 & 2102 & 877 & -311 & 568 \\
\hline & 平均值 Mean & $2257 \mathrm{Aa}$ & $1217 \mathrm{Aa}$ & $1831 \mathrm{Ab}$ & $1040 \mathrm{Aa}$ & $-393 \mathrm{Bb}$ & $648 \mathrm{Bb}$ \\
\hline 高产不优质 & 武运 5051 Wuyun 5051 & 2451 & 1649 & 2658 & 802 & 207 & 1009 \\
\hline \multirow[t]{3}{*}{$\mathrm{HB}$} & 扬粳 1612 Yangjing 1612 & 2565 & 1625 & 2633 & 940 & 68 & 1008 \\
\hline & 华粳 8 号 Huajing 8 & 2178 & 1381 & 2378 & 797 & 200 & 997 \\
\hline & 平均值 Mean & $2398 \mathrm{Aa}$ & $1552 \mathrm{Aa}$ & $2556 \mathrm{Aa}$ & $846 \mathrm{Ab}$ & $158 \mathrm{Aa}$ & $1005 \mathrm{Aa}$ \\
\hline 中产优质 & 福粳 1606 Fujing 1606 & 2718 & 1551 & 2338 & 1167 & -380 & 787 \\
\hline \multirow[t]{3}{*}{ MG } & 苏香粳 3 号 Suxiangjing 3 & 2484 & 1349 & 2177 & 1135 & -307 & 828 \\
\hline & 松早香 1 号 Songzaoxiang 1 & 2764 & 1848 & 2558 & 916 & -206 & 710 \\
\hline & 平均值 Mean & $2655 \mathrm{Aa}$ & $1583 \mathrm{Aa}$ & $2358 \mathrm{Aa}$ & $1073 \mathrm{Aa}$ & $-298 \mathrm{Bb}$ & $775 \mathrm{ABb}$ \\
\hline \multicolumn{2}{|c|}{ 年度间 Between years } & $\mathrm{ns}$ & ns & ns & ns & ns & ns \\
\hline
\end{tabular}

同一品种同列数据后不同小、大写字母分别表示处理间差异达 $5 \%$ 和 $1 \%$ 显著水平。ns 表示差异不显著。缩写同表 2 。

Values for a cultivar within a column followed by different lowercase and capital letters are significantly different at the $5 \%$ and $1 \%$ probability levels, respectively. ns: not significant. Abbreviations are the same as those given in Table 2.

表 92017 年不同类型常规粳稻生育期及灌浆结实期温光

Table 9 Growth period and temperature and light during the grain filling period in different types of conventional japonica rice in 2017

\begin{tabular}{|c|c|c|c|c|c|c|c|c|}
\hline \multirow[b]{2}{*}{$\begin{array}{l}\text { 品种类型 } \\
\text { Type }\end{array}$} & \multirow[b]{2}{*}{$\begin{array}{l}\text { 品种名称 } \\
\text { Cultivar }\end{array}$} & \multicolumn{3}{|c|}{$\begin{array}{c}\text { 灌浆结实期 } \\
\text { Grain filling period }\end{array}$} & \multicolumn{4}{|c|}{$\begin{array}{c}\text { 灌浆结实期温光 } \\
\text { Temperature and light in grain filling period }\end{array}$} \\
\hline & & $\begin{array}{c}\text { 抽穗期 } \\
\text { Jointing } \\
\text { (month/day) }\end{array}$ & $\begin{array}{c}\text { 成熟期 } \\
\text { Heading } \\
\text { (month/day) }\end{array}$ & $\begin{array}{l}\text { 天数 } \\
\text { Days } \\
\text { (d) }\end{array}$ & $\begin{array}{c}\text { 日平均温度 } \\
\text { Mean daily } \\
\text { temperature } \\
\left({ }^{\circ} \mathrm{C}\right)\end{array}$ & $\begin{array}{c}\text { 积温 } \\
\text { Accumulated } \\
\text { temperature } \\
\left({ }^{\circ} \mathrm{C}\right)\end{array}$ & $\begin{array}{l}\text { 日照时数 } \\
\text { Sunshine } \\
\text { hours (h) }\end{array}$ & $\begin{array}{c}\text { 降雨量 } \\
\text { Rainfall } \\
(\mathrm{mm})\end{array}$ \\
\hline \multirow{4}{*}{$\begin{array}{l}\text { 高产优质 } \\
\text { HG }\end{array}$} & 南粳 9108 Nanjing 9108 & $8 / 25$ & $10 / 21$ & 57 & 20.77 & 624.90 & 215.60 & 444.50 \\
\hline & 南粳 505 Nanjing 505 & $8 / 20$ & $10 / 25$ & 66 & 21.06 & 720.70 & 256.30 & 464.20 \\
\hline & 徐稻 9 号 Xudao 9 & $8 / 28$ & $10 / 25$ & 58 & 20.38 & 644.90 & 214.60 & 444.50 \\
\hline & 平均值 Mean & - & - & $60 \mathrm{Aab}$ & $20.74 \mathrm{Aa}$ & 663.50 Aab & $228.83 \mathrm{Aab}$ & $451.07 \mathrm{Aa}$ \\
\hline 高产不优质 & 武运 5051 Wuyun 5051 & $8 / 22$ & $10 / 24$ & 63 & 20.93 & 699.70 & 236.10 & 464.20 \\
\hline \multirow[t]{3}{*}{$\mathrm{HB}$} & 扬粳 1612 Yangjing 1612 & $8 / 25$ & $10 / 28$ & 63 & 20.25 & 676.40 & 246.80 & 444.50 \\
\hline & 华粳 8 号 Huajing 8 & $8 / 22$ & $10 / 25$ & 64 & 20.85 & 705.10 & 239.50 & 464.20 \\
\hline & 平均值 Mean & - & - & $63 \mathrm{Aa}$ & $20.68 \mathrm{Aa}$ & $693.73 \mathrm{Aa}$ & $240.80 \mathrm{Aa}$ & $457.63 \mathrm{Aa}$ \\
\hline 中产优质 & 福粳 1606 Fujing 1606 & $8 / 26$ & $10 / 19$ & 54 & 20.45 & 603.61 & 201.30 & 425.00 \\
\hline \multirow[t]{3}{*}{ MG } & 苏香粳 3 号 Suxiangjing 3 & $8 / 18$ & $10 / 11$ & 54 & 20.29 & 598.85 & 214.80 & 418.60 \\
\hline & 松早香 1 号 Songzaoxiang 1 & $8 / 20$ & $10 / 9$ & 50 & 20.15 & 517.65 & 205.70 & 396.10 \\
\hline & 平均值 Mean & - & - & $53 \mathrm{Ab}$ & $20.30 \mathrm{Aa}$ & $573.37 \mathrm{Ab}$ & $207.27 \mathrm{Ab}$ & $413.23 \mathrm{Ab}$ \\
\hline
\end{tabular}

同一品种同列数据后不同小、大写字母分别表示处理间差异达 $5 \%$ 和 $1 \%$ 显著水平。缩写同表 2 。

Values for a cultivar within a column followed by different lowercase and capital letters are significantly different at the $5 \%$ and $1 \%$ probability levels, respectively. Abbreviations are the same as those given in Table 2. 


\section{3 讨论}

\section{1 适合安徽沿淮地区种植的优质高产粳稻品} 种的篮选

对于适宜地区优质高产品种的篮选，主要从生 育期、产量、品质等方面进行。生育期决定了水稻 的种植区域，过早不能充分利用温光资源，而过晚 不能正常抽穗成熟，都严重影响产量和品质 ${ }^{[14]}$ 。本 试验所有品种生育期在 135 160 d 左右, 跨度较大, 因此首先需要篮选出适宜生育期范围的品种。安徽 沿淮地区属于稻麦两熟制, 篮选出的粳稻品种要满 足播种时间在 5 月 5 日至 5 月 15 日，移栽期在 6 月 5 日至 6 月 15 日, 最适抽穗期在 8 月 20 日至 9 月 5 日，收获期在 10 月 22 日至 11 月 10 日。全生育期 积温范围在 3990.1 4269.9 ${ }^{\circ} \mathrm{C}$ d，降雨量范围在 $446.5 \sim 987.5 \mathrm{~mm}^{[15]}$, 并且水稻灌浆结实初期温度要 尽量保证在 $21 \sim 26^{\circ} \mathrm{C}$ 范围内 ${ }^{[16]}$,才有可能在保证正 常成熟的情况下稳产继而达到高产。产量方面, 本 试验中的 74 个品种在 $5.51 \sim 9.28 \mathrm{t} \mathrm{hm}^{-2}$ 之间, 高产与 否很大程度上取决于其在该地区种植能否形成足够 的群体颖花量、较高的结实率和千粒重 ${ }^{[1]}$, 本试验高 产类型在产量构成因素上具有单位面积穗数低、每 穗粒数高、结实率高、千粒重高的特点, 尤以每穗 粒数极显著高于中产类型。因此在产量指标的篮选 上要综合考虑足量的群体穗数与较大的穗型协调产 出足够的群体颖花量, 并保证正常的灌浆充实, 即 保持较高的结实率和千粒重, 往往能在一定程度上 保证产量的稳定以达到高产。品质方面, 优质与否 主要看品种的加工、外观、蒸者食味、营养品质等, 本研究从食味值评分篮选后发现，所有品种的食味 值评分在 40 74, 而达到优质品种的食味值评分在 60 74 之间。直链淀粉 ${ }^{[17]}$ 和蛋白质含量 ${ }^{[18]}$ 是影响稻 米蒸者食味品质的重要因素, 直链淀粉含量越高, 蒸者食味品质越差 ${ }^{[19-20]}$; 蛋白质含量越高, 米饭质 地越硬, 口感越差 ${ }^{[21]}$; 孟庆虹等 ${ }^{[22-23]}$ 认为, 蛋白质 含量控制在 $6.5 \%$ $7.5 \%$, 直链淀粉含量控制在 $15.0 \%$ 16.5\%可提高稻米的食味。因此，综合考虑直 链淀粉含量、蛋白质含量、食味值评分等条件, 可 篮选出优质的品种。

3.2 适合安徽沿淮地区种植的优质高产粳稻的 特征特性

根据安徽沿淮地区粳稻的耕作制度、适宜生育 期范围并结合当地的温光条件, 本实验篮选出的高 产优质类型品种生育期在 150 160 d 左右, 在 5 月中
旬播种，8 月下旬到 9 月上旬之间完成抽穗，10月 20 日到 10 月 30 日之间成熟, 抽穗期至成熟期在 $60 \mathrm{~d}$ 左右, 灌浆结实期日平均气温在 $21^{\circ} \mathrm{C}$ 左右, 该时期积温在 $600^{\circ} \mathrm{C}$ 以上, 降雨量在 $400 \mathrm{~mm}$ 以上, 能充分利用当地的温光资源，在正常成熟的基础 上达到高产。

关于粳稻产量与产量构成因素之间的关系，前 人的研究认为, 足量群体穗数和较大的穗型及较高 的结实率和千粒重是粳稻获得高产的关键 ${ }^{[1]}$ 。本研 究篮选出的高产品种, 单位面积穗数在 $310 \times 10^{4} \sim$ $320 \times 10^{4} \mathrm{hm}^{-2}$ 之间，穗粒数 140 左右，结实率 $85 \%$ 左 右, 千粒重 $25 \mathrm{~g}$ 左右, 方差分析显示, 高产类型和 中产类型的差异主要表现在单位面积穗数、每穗粒 数和结实率, 尤以每穗粒数在两者之间差异极显著, 推测可能是不同品种穗型不同导致的。对于结实率 和粒重, 灌浆结实期是关键时期 ${ }^{[24]}$, 灌浆结实至成 熟期间, 光合产物被输送至籽粒并形成产量, 其过 程不仅与品种特性、光合产物的供应、运转等内在 因素有关，还受到外界环境的影响，其中包括温度、 光照、降雨量等。本试验中, 高产类型的总生育期、 灌浆结实天数、日照时数、积温和降雨量都高于中 产类型，尤以高产不优质类型显著高于中产优质类 型, 较优的温光条件使得高产类型弱势粒、痻粒及 低位穗在灌浆中后期缓慢充实 ${ }^{[25-26]}$ ，提高了结实率 和粒重, 进而产量高于中产类型。龚金龙等 ${ }^{[27]}$ 在粳 稻生育期与温光资源利用特征差异研究中认为, 延 长生育期, 尤其是灌浆结实期, 能提高有效积温和 光合有效辐射, 是粳稻高产的重要途径, 这与本文 高产类型灌浆结实期、总生育期比中产类型长的研 究结果相似。所以在整个生育期温光资源利用合理, 物质积累充足的基础上, 选择总生育期且灌浆结实 期略长的品种，有利于籽粒和穗在灌浆结实期积累 足够的有效积温和光合产物，在一定程度上保证产 量的提高。

关于优质稻米品质指标的特征特性, 前人已有 研究 ${ }^{[28-31]}$ 。本研究结果显示, 篮选出的优质高产粳 稲品种在加工品质方面, 出樯率达到国标 1 级, 整 精米率达到国标 3 级及以上标准; 在外观上, 透明 度在 2 4 级不等, 而严白粒率在 $30 \% \sim 70 \%$ 不等, 严 白度在 $10 \% \sim 20 \%$ 不等，几乎都末达到我国优质稻米 质量指标。这与传统意义上优质米的严白度、严白 粒率偏低的结果有所差别。本试验造成这种外观差 异可能是精米在存放一段时间后，由于水分较低等 
原因而出现暗胚乳表型 ${ }^{[32-33]}$, 使精米透明度较差, 导致仪器或人眼外观检测时将其误判为严白, 使严 白度、严白率数据偏高。

本试验篮选出的优质高产粳稻品种的直链淀粉 含量、蛋白质含量达到国家优质稻谷质量指标, 胶 稠度达到国标 2 级及以上标准。优质具体表现为直 链淀粉含量、蛋白质含量较低而胶稠度较高, 且在 优质与不优质之间达到极显著或显著差异。张桂莲 等 ${ }^{[34]}$ 研究发现抽穗结实期相对较高温使直链淀粉含 量增加, 除品种因素外, 因温度影响同一品种直链 淀粉含量可相差 $6.00 \% \sim 8.21 \%{ }^{[35-36]}$ 。本试验结果表 明, 不同类型常规粳稻灌浆结实期的日平均温度在 适宜的范围内 $\left(21^{\circ} \mathrm{C}\right.$ 左右 $)$, 且无显著差异, 推测可能 是粳稻品种自身因素导致的直链淀粉含量差异; 与 此同时, 稻米胶稠度与直链淀粉含量有关, 直链淀 粉含量低或中等的品种胶稠度较软, 直链淀粉含量 高的品种胶稠度较硬 ${ }^{[37]}$,一般认为, 胶稠度越软, 其流动性和延展性越好, 流胶长度越长 ${ }^{[38]}$, 本研究 中, 优质、不优质类型之间的表现与此一致。粳稻 的蛋白质含量一般在 $5 \% \sim 16 \%{ }^{[39]}$, 张晓 ${ }^{[40]}$ 研究认为, 蛋白质含量高会抑制淀粉粒吸水、膨胀及糊化, 使 米饭变硬, 导致品质变劣, 超过 $9 \%$ 会影响食味品质; 一般蒸煮食味品质优秀的品种, 其蛋白质含量应不 高于 $9 \%{ }^{[41]}$, 降低蛋白质含量能够提高稻米蒸煮食 味品质 ${ }^{[42]}$, 而本研究䇻选出的优质品种蛋白质含量 在 $6 \%$ \% 8 之间, 达到了优质食味稻米的要求。

本试验中, 高产优质类型粳稻 RVA 谱特征值中 的消减值与回复值低于非优质食味类型, 这与胡蕾 等 ${ }^{[5]}$ 的优良食味与高产协同的单季晚粳稻, 与味中 高产类型相比, 消减值与回复值偏低的特点结论一 致。有研究发现过高的蛋白质含量对稻米的外观和 食味品质有不良影响 ${ }^{[43]}$, 而胶稠度越长, 消减值越 小, 米饭柔软性、黏散性及综合评分越高, 口感越 好 $^{[44-45]}$, 食味值越高, 本试验通过 3 个类型品种的 比较, 也得出了相似的结果。高产优质类型粳稻在 食味值综合评价方面有外观好、硬度小、黏度大、 平衡度高的特点, 在 RVA 谱特征值上表现为消减值 小于-200 cP, 崩解值在 $1000 \mathrm{cP}$ 左右。朱盈等 ${ }^{[9]}$ 節选 出优良食味与高产协同的中熟常规粳稻在食味值综 合评价方面的特征表现, 与本文得出的结论相似。

\section{4 结论}

依据常规粳稻品种产量及其构成因素、食味值
评分、直链淀粉含量、蛋白质含量、胶稠度等, 篮 选出一批在沿淮地区产量潜力大、品质较优的常规 粳稻品种。这些高产优质粳稻品种的特征及与其他 两种类型表现出显著或极显著差异的指标主要表现 为, 产量在 $8.35 \sim 9.16 \mathrm{t} \mathrm{hm}^{-2}$, 单位面积穗数在 $310 \times 10^{4} \sim 320 \times 10^{4} \mathrm{hm}^{-2}$ 之间, 每穗粒数在 140 左右, 千粒重在 $25 \mathrm{~g}$ 以上; 食味值评分在 $60 \sim 74$, 胶稠度 长度在 $80 \sim 90 \mathrm{~mm}$, 蛋白质含量在 $6 \% \sim 8 \%$ 以内; 在 RVA 谱特征值中崩解值在 $1000 \mathrm{cP}$ 左右, 而消减值 在-200 cP 以下。

\section{References}

[1] 张洪程, 张军, 龚金龙, 常勇, 李敏, 高辉, 戴其根, 霍中洋, 许轫, 魏海燕. “籼改粳”的生产优势及其形成机理. 中国农业 科学, 2013, 46: 686-704.

Zhang H C, Zhang J, Gong J L, Chang Y, Li M, Gao H, Dai Q G, Huo Z Y, Xu K, Wei H Y. The productive advantages and formation mechanisms of "indica rice to japonica rice". Sci Agric Sin, 2013, 46: 686-704 (in Chinese with English abstract).

[2] 李旭毅, 池忠志, 姜心禄, 郑家国. 成都平原两熟区籼粳稻品 种籽粒灌浆特性. 中国农业科学, 2012, 45: 3256-3264.

Li X Y, Chi Z Z, Jiang X L, Zheng J G. Analysis on grain filling characteristics of indica and japonica rice in rapeseed (wheat) -rice planting area in Chengdu Basin. Sci Agric Sin, 2012, 45: 3256-3264 (in Chinese with English abstract).

[3] 卜祥. 粳稻潜力待挖. 农经杂志, 2011, (2): 42-44.

$\mathrm{Bu}$ X. The potential of japonica rice can be explored. Agric Econ Mag, 2011, (2): 42-44 (in Chinese).

[4] 凌启鸿, 张洪程, 苏祖芳, 郭文善, 陈德华, 陆卫平, 冷锁虎, 凌励, 杨建昌, 丁艳锋, 吴云康, 曹显祖, 朱庆森, 朱耕如. 作 物群体质量. 上海: 上海科学技术出版社, 2000 .

Ling Q H, Zhang H C, Su Z F, Guo W S, Chen D H, Lu W P, Leng S H, Ling L, Yang J C, Ding Y F, Wu Y K, Cao X Z, Zhu Q S, Zhu G R. Quality of Crop Population. Shanghai: Shanghai Scientific and Technical Publisher, 2000 (in Chinese).

[5] 胡蕾, 朱盈, 徐栋, 陈志峰, 胡兵强, 韩超, 表实, 吴培, 张洪 程, 魏海燕. 南方稻区优良食味与高产协同的单季晚粳稻品 种特点研究. 中国农业科学, 2019, 52: 215-227.

Hu L, Zhu Y, Xu D, Chen Z F, Hu B Q, Han C, Qiu S, Wu P, Zhang H C, Wei H Y. Characteristics of good taste and high yield type of single cropping late japonica rice in southern China. Sci Agric Sin, 2019, 52: 215-227 (in Chinese with English abstract).

[6] 花劲, 周年兵, 张洪程, 霍中洋, 许轫, 魏海燕, 高辉, 郭保卫, 戴其根, 张军, 周培建, 程飞虎, 黄大山, 陈忠平, 陈国梁. 南 方粳稻生产与发展研究及对策. 中国稻米, 2014, 20(1): 5-11.

Hua J, Zhou N B, Zhang H C, Huo Z Y, Xu K, Wei H Y, Gao H, Guo B W, Dai Q G, Zhang J, Zhou P J, Cheng F H, Huang D S, Chen Z P, Chen G L. Situation and strategies of japonica rice production and development in southern China. China Rice, 2014, 20(1): 5-11 (in Chinese with English abstract).

[7] 陈波, 周年兵, 郭保卫, 黄大山, 陈忠平, 花劲, 霍中洋, 张洪 程. 南方稻区“籼改粳” 研究进展. 扬州大学学报(农业与生 命科学版), 2017, 38(1): 67-72. 
Chen B, Zhou N B, Guo B W, Huang D S, Chen Z P, Hua J, Huo Z Y, Zhang H C. Progress of "indica rice to japonica rice" in southern China. J Yangzhou Univ (Agric \& Life Sci Edn), 2017, 38(1): 67-72 (in Chinese with English abstract).

[8] 习敏, 吴文革, 陈刚, 许有尊, 杨惠成, 周永进, 孙雪原. 安徽 省粳稻生产现状及籼改粳发展潜力分析. 中国稻米, 2018, 24(2): 70-75.

Xi M, Wu W G, Chen G, Xu Y Z, Yang H C, Zhou Y J, Sun X Y. Production situation and development potential of japonica rice in Anhui province. China Rice, 2018, 24(2): 70-75 (in Chinese with English abstract).

[9] 朱盈, 徐栋, 胡蕾, 花辰, 陈志峰, 张振振, 周年兵, 刘国栋, 张洪程, 魏海燕. 江淮优良食味高产中熟常规粳稻品种的特 征. 作物学报, 2019, 45: 578-588.

Zhu Y, Xu D, Hu L, Hua C, Chen Z F, Zhang Z Z, Zhou N B, Liu G D, Zhang H C, Wei H Y. Characteristics of medium-maturity conventional japonica rice with good taste and high yield in Jianghuai area. Acta Agron Sin, 2019, 45: 578-588 (in Chinese with English abstract).

[10] 于洪兰, 王伯伦, 王术, 佟伟, 王一, 黄元财, 蒋文春. 不同类 型水稻品种的产量与食味品质的关系比较. 作物杂志, 2009 , (1): 46-49.

Yu H L, Wang B L, Wang S, Tong W, Wang Y, Huang Y C, Jiang W C. Comparison of relationships between yield and eating quality in different types of rice varieties. Crops, 2009, (1): 46-49 (in Chinese with English abstract).

[11] 钟旭华, 彭少兵, Sheehy J E, 刘鸿先. 水稻群体成穗率与干物 质积累动态关系的模拟研究. 中国水稻科学, 2001, 15: 107-112.

Zhong X H, Peng S B, Sheehy J E, Liu H X. Relationship between productive tiller percentage and biomass accumulation in rice (Oryza sativa L.): a simulation approach. Chin J Rice Sci, 2001, 15: 107-112 (in Chinese with English abstract).

[12] 彭显龙, 刘元英, 罗盛国, 范立春, 宋添星, 郭艳文. 实地氮 肥管理对寒地水稻干物质积累和产量的影响. 中国农业科学, 2006, 39: 2286-2293.

Peng X L, Liu Y Y, Luo S G, Fan L C, Song T X, Guo Y W. Effects of the site-specific nitrogen management on yield and dry matter accumulation of rice in cold areas of northeastern China. Sci Agric Sin, 2006, 39: 2286-2293 (in Chinese with English abstract).

[13] 杨建昌. 水稻弱势粒灌浆机理与调控途径. 作物学报, 2010, 36: 2011-2019.

Yang J C. Mechanism and regulation in the filling of inferior spikelets of rice. Acta Agron Sin, 2010, 36: 2011-2019 (in Chinese with English abstract).

[14] 徐正进, 陈温福. 中国北方粳型超级稻研究进展. 中国农业科 学, 2016, 49: 239-250.

$\mathrm{Xu}$ Z J, Chen W F. Research progress and related problems on japonica super rice in northern China. Sci Agric Sin, 2016, 49: 239-250 (in Chinese with English abstract).

[15] 杜祥备, 孔令聪, 习敏, 吴文革, 陈金华, 岳伟. 江淮区域稻 麦两熟制周年资源分配、利用特征. 中国生态农业学报, 2019, 27: 1078-1087.

Du X B, Kong L C, Xi M, Wu W G, Chen J H, Yue W. Characteristics of resource allocation and utilization of rice-wheat double cropping system in the Jianghuai area. Chin J Eco-Agric, 2019, 27: 1078-1087 (in Chinese with English abstract).

[16] 龚金龙, 张洪程, 胡雅杰, 龙厚元, 常勇, 王艳, 邢志鹏, 霍中 洋. 灌浆结实期温度对水稻产量和品质形成的影响. 生态学 杂志, 2013, 32: 482-491.

Gong J L, Zhang H C, Hu Y J, Long H Y, Chang Y, Wang Y, Xing Z P, Huo Z Y. Effects of air temperature during rice grain-filling period on the formation of rice grain yield and its quality. Chin $J$ Ecol, 2013, 32: 482-491 (in Chinese with English abstract).

[17] 高焕晔, 王三根, 宗学凤, 腾中华, 赵芳明, 刘照. 灌浆结实 期高温干旱复合胁迫对稻米直链淀粉及蛋白质含量的影响. 中国生态农业学报, 2012, 20: 40-47.

Gao H Y, Wang S G, Zong X F, Teng Z H, Zhao F M, Liu Z. Effects of combined high temperature and drought stress on amylose and protein contents at rice grain-filling stage. Chin $J$ Eco-Agric, 2012, 20: 40-47 (in Chinese with English abstract).

[18] 钱春荣, 冯延江, 杨静, 刘海英, 金正勋. 水稻籽粒蛋白质含 量选择对杂种早代蒸煮食味品质的影响. 中国水稻科学, 2007, 21: 323-326.

Qian C R, Feng Y J, Yang J, Liu H Y, Jin Z X. Effects of protein content selection on cooking and eating properties of rice in early-generation of crosses. Chin J Rice Sci, 2007, 21: 323-326 (in Chinese with English abstract).

[19] Taghinezhad E, Khoshtaghaza M H, Minaei S, Suzuki T, Brenner T. Relationship between degree of starch gelatinization and quality attributes of parboiled rice during steaming. J Integr Agric, 2016, 23: 339-344.

[20] Pan T, Zhao L X, Lin L S, Wang J, Liu Q Q, Wei C X. Changes in kernel morphology and starch properties of high-amylose brown rice during the cooking process. Food Hydrocolloids, 2017, 66: 227-236.

[21] 徐栋, 朱盈, 周否, 韩超, 郑雷鸣, 张洪程, 魏海燕, 王玨, 廖 桉桦, 蔡仕博. 不同类型籼粳杂交稻产量和品质性状差异及 其与灌浆结实期气候因素间的相关性. 作物学报, 2018, 44: $1548-1559$.

Xu D, Zhu Y, Zhou L, Han C, Zheng L M, Zhang H C, Wei H Y, Wang J, Liao A H, Cai S B. Differences in yield and grain quality among various types of indica/japonica hybrid rice and correlation between quality and climatic factors during grain filling period. Acta Agron Sin, 2018, 44: 1548-1559 (in Chinese with English abstract).

[22] 孟庆虹, 程爱华, 姚傘金沝, 张瑞英, 陈凯新, 李霞辉. 粳稻食 味品质评价方法的研究. 北方水稻, 2008, 38(6): 24-28.

Meng Q H, Cheng A H, Yao X M, Zhang R Y, Chen K X, Li X H. Study on palatability evaluation method of japonica rice. North Rice, 2008, 38(6): 24-28 (in Chinese with English abstract).

[23] 徐铨, 唐亮, 徐凡, 福嶌阳, 黄瑞冬, 陈温福, 徐正进. 粳稻食 味品质改良研究现状与展望. 作物学报, 2013, 39: 961-968.

Xu Q, Tang L, Xu F, Fu D Y, Huang R D, Chen W F, Xu Z J. Research advances and prospects of eating quality improvement in japonica rice (Oryza sativa L.). Acta Agron Sin, 2013, 39: 961-968 (in Chinese with English abstract).

[24] 陆魁东, 宁金花, 宋忠华, 张艳桂, 谢佰承. 超级晚稻灌浆特 性与温光条件的关系. 中国农业气象, 2015, 36: 732-738. Lu K D, Ning J H, Song Z H, Zhang Y G, Xie B C. Relationship 
between the grain filling characteristics of hybrid rice and temperature and light factors. Chin J Agrometeorol, 2015, 36: 732-738 (in Chinese with English abstract).

[25] 程方民, 钟连进, 孙宗修. 灌浆结实期温度对早籼水稻籽粒淀 粉合成代谢的影响. 中国农业科学, 2003, 36: 492-501.

Cheng F M, Zhong L J, Sun Z X. Effect of temperature at grain-filling stage on starch biosynthetic metabolism in developing rice grains of early-indica. Sci Agric Sin, 2003, 36: 492-501 (in Chinese with English abstract).

[26] 刘从军. 温光条件对水稻籽粒灌浆特性及稻米品质的影响. 四川农业大学硕士学位论文, 四川雅安, 2003.

Liu C J. Effects of Temperature and Light Conditions on Rice Grain-filling Characteristics and Rice Quality. MS Thesis of Sichuan Agricultural University, Ya'an, Sichuan, China, 2003 (in Chinese with English abstract).

[27] 龚金龙, 邢志鹏, 胡雅杰, 张洪程, 戴其根, 霍中洋, 许轫, 魏 海燕, 高辉. 江淮下游地区籼粳超级稻生育期与温光资源利 用特征的差异研究. 中国水稻科学, 2014, 28: 267-276.

Gong J L, Xing Z P, Hu Y J, Zhang H C, Dai Q G, Huo Z Y, Xu K, Wei H Y, Gao H. Difference in growth duration and utilization of temperature and solar radiation between indica and japonica super rice in the lower Yangtze and Huaihe river valley. Chin J Rice Sci, 2014, 28: 267-276 (in Chinese with English abstract).

[28] 刘贺梅. 水稻加工品质与外观品质 QTL 分析. 中国农业科学 院硕士学位论文, 北京, 2010.

Liu H M. QTLs Analysis of Processing Quality and Appearance Quality of Rice. MS Thesis of Chinese Academy of Agricultural Sciences, Beijing, China, 2010 (in Chinese with English abstract).

[29] Fitzgerald M A, McCouch S R, Hall R D. Not just a grain of rice: the quest for quality. Trends Plant Sci, 2009, 14: 133-139.

[30] 张昌泉, 赵冬生, 李钱峰, 顾铭洪, 刘巧泉. 稻米品质性状基 因的克隆与功能研究进展.中国农业科学，2016，49: 4267-4283.

Zhang C Q, Zhao D S, Li Q F, Gu M H, Liu Q Q. Progresses in research on cloning and functional analysis of key genes involving in rice grain qualiy. Sci Agric Sin, 2016, 49: 4267-4283 (in Chinese with English abstract).

[31] Sreenivasulu N, Butardo V M, Misra G, Cuevas R P, Anacleto R, Kishor P B K. Designing climate-resilient rice with ideal grain quality suited for high-temperature stress. $J$ Exp Bot, 2015, 66: 1737.

[32] 吴殿星, 夏英武, 李旭晨. 水稻胚乳外观云雾性状形成基础及 其快速识别条件分析. 中国水稻科学, 2001, 15: 192-196. Wu D X, Xia Y W, Li X C. Formation basis of rice mist endosperm appearance and its rapid identifying factors. Chin J Rice Sci, 2001, 15: 192-196 (in Chinese with English abstract).

[33] Chen T, Zhang Y D, Zhao L, Zhu Z, Lin J, Zhang S B. A cleaved amplified polymorphic sequence marker to detect variation in $W x$ locus conditioning translucent endosperm in rice. Chin J Rice Sci, 2009, 16: 106-110.

[34] 张桂莲, 张顺堂, 王力, 肖应辉, 唐文帮, 陈光辉, 陈立云. 抽 穗结实期不同时段高温对稻米品质的影响. 中国农业科学, 2013, 46: 2869-2879
Zhang G L, Zhang S T, Wang L, Xiao Y H, Tang W B, Chen G H, Chen L Y. Effects of high temperature at different times during the heading and filling periods on rice quality. Sci Agric Sin, 2013, 46: 2869-2879 (in Chinese with English abstract).

[35] 盛婧, 陶红娟, 陈留根. 灌浆结实期不同时段温度对水稻结实 与稻米品质的影响. 中国水稻科学, 2007, 21: 396-402.

Sheng J, Tao H J, Chen L G. Response of seed-setting and grain quality of rice to temperature at different time during grain filling period. Chin J Rice Sci, 2007, 21: 396-402 (in Chinese with English abstract).

[36] 董明辉, 陈培峰, 乔中英, 吴翔宙, 赵步洪, 蒋媛媛, 杨建昌. 水稻不同粒位籽粒米质对花后不同时段温度胁迫的响应. 作 物学报, 2011, 37: 506-513.

Dong M H, Chen P F, Qiao Z Y, Wu X Z, Zhao B H, Jiang Y Y, Yang J C. Effect of temperature at different durations after anthesis on rice quality and variations between positions on a panicle. Acta Agron Sin, 2011, 37: 506-513 (in Chinese with English abstract).

[37] 莫惠栋. 我国稻米品质的改良. 中国农业科学, 1993, 26 (4): $8-14$.

Mo H D. Quality improvement of rice grain in China. Sci Agric Sin, 1993, 26(4): 8-14 (in Chinese).

[38] Gomez K A. Effect of environment on protein and amylose content of rice. In: Chemical Aspects of Rice Grain Quality. Manila, Philippines: IRRI, 1979. pp 59-68.

[39] 李坤. 低直链淀粉含量、低蛋白质含量粳稻资源品质性状研究. 沈阳农业大学硕士学位论文, 辽宁沈阳, 2016.

Li K. Study of Japonica Rice Resources Quality Traits on Low Amylose Content and Low Protein Content. MS Thesis of Shenyang Agricultural University, Shenyang, Liaoning, China, 2016 (in Chinese with English abstract).

[40] 张晓. 杂交水稻种子淀粉、蛋白质、脂肪含量对其活力影响的 初步研究. 浙江农林大学硕士学位论文, 浙江杭州, 2014.

Zhang X. A Preliminary Study on the Effects of Seed Starch, Protein, Fat Protein on Seed Vigor of Hybrid Rice. MS Thesis of Zhejiang A\&F University, Hangzhou, Zhejiang, China, 2014 (in Chinese with English abstract).

[41] 张启莉, 谢黎虹, 李仕贵, 胡培松. 稻米蛋白质与蒸煮食味品 质的关系研究进展. 中国稻米, 2012, 18(4): 1-6.

Zhang Q L, Xie L H, Li S G, Hu P S. Research progress of the relationship between rice protein and cooking and eating quality. China Rice, 2012, 18(4): 1-6 (in Chinese).

[42] 谢黎虹, 陈能, 段涁伍, 朱智伟. 稻米中蛋白质对淀粉 RVA 特 征谱的影响. 中国水稻科学, 2006, 20: 524-528.

Xie L H, Chen N, Duan B W, Zhu Z W. Effects of proteins on RVA viscosity properties of rice. Chin J Rice Sci, 2006, 20: 524-528 (in Chinese with English abstract).

[43] 陈能, 罗玉坤, 谢黎虹, 朱智伟, 段彬伍, 章林平. 我国水稻 品种的蛋白质含量及与米质的相关性研究. 作物学报, 2006, 32: 1193-1196.

Chen N, Luo Y K, Xie L H, Zhu Z W, Duan B W, Zhang L P. Protein content and its correlation with other quality parameters of rice in China. Acta Agron Sin, 2006, 32: 1193-1196 (in Chinese with English abstract). 
[44] 蔡一霞, 刘春香, 王维, 张洪熙, 张祖建, 杨静, 唐汉忠. 灌浆 期表观直链淀粉含量相似品种稻米胶稠度和 RVA 谱的动态差 异. 中国农业科学, 2011, 44: 2439-2445.

Cai Y X, Liu C X, Wang W, Zhang H X, Zhang Z J, Yang J, Tang H Z. Dynamic differences of the RVA profile and gel consistency in two rice varieties with similar apparent amylose content during grain filling. Sci Agric Sin, 2011, 44: 2439-2445 (in Chinese with
English abstract).

[45] 胡培松, 翟虎渠, 唐绍清, 万建民. 利用 RVA 快速鉴定稻 米蒸者及食味品质的研究. 作物学报, 2004: 519-524.

Hu P S, Zhai H Q, Tang S Q, Wan J M. Rapid evaluation of rice cooking and palatability quality by RVA profile. Acta Agron Sin, 2004, 30: 519-524 (in Chinese with English abstract). 